\title{
Túlnépesedő világ?! A fertilitási ráták elemzése
}

\section{An overpopulated World?!}

\author{
The Analysis of Fertility Rates
}

\section{ÖSSZEFOGLALÁS}

A teljes termékenységi arányszám és reprodukciós szinthez tartozó fertilitási ráta értéke alapvetően határozza meg egy ország hosszú távú demográfiai arculatát. Globális szinten a két mutató értéke az elmúlt években jelentősen csökkent, ám a két ráta közötti különbség szűkülésével a világ globális népességnövekedés lassulni kezdett. Egy demográfiai változókra vonatkozó átfogó klaszterelemzés eredményei alapján megállapítottam, hogy a demográfiai átmenet hossza az egyes régiókban jelentősen eltér. Az amerikai és ázsiai kontinens országaiban összességében a demográfiai átmenet sokkal gyorsabban megy végbe, az afrikai országokban azonban az átmenet jóval lassabb, a fertilitási ráták továbbra is magas értékeket vesznek fel. Emiatt a „túlnépesedő” kifejezés már inkább csak a fejletlenebb afrikai térségekre vonatkoztatható, a legtöbb fejlődő országban a jövőben a túlnépesedés helyett sokkal inkább az elöregedés jelenthet fokozódó problémát.

Journal of Economic Literature (JEL) kódok: J11, J13, N30
Kulcsszavak: népességnövekedés, teljes termékenységi arányszám, reproduktivitás, reprodukciós szinthez tartozó fertilitási ráta

\section{SumMary}

The value of the total fertility rate and the replacement fertility rate determines a country's longterm demographic image. At a global level, the values of the two indicators have declined significantly in recent years, but as the gap between the two rates has been narrowing, global population growth has begun to slow. Based on the results of a comprehensive cluster analysis of demographic variables, I found that the length of the demographic transition varies significantly from region to region. Overall, in the countries of the Americas and the Asian continent, the demographic transition is much faster, but in African countries, the transition is much slower, and fertility rates continue to take high values. For this reason, the term "overpopulation" can now only be applied to less developed regions of Africa, and in most developing countries, aging, rather than overpopulation, may pose a significant problem in the future.

Drabancz Áron, doktorandusz, Budapesti Corvinus Egyetem (aron.drabancz@ gmail.com). 
Journal of Economic Literature (JEL) codes: J11, J13, N30

Keywords: population growth, total fertility rate, reproductivity, replacement fertility rate

\section{Bevezetés}

A világ népessége egy hosszú folyamat végén lassan a demográfiai átmenet utolsó fázisába lép. A demográfiai átmenet első fázisa nagyjából az ipari forradalom kezdetéig állt fenn, ameddig a magas halálozási és születési számok stagnáló, lassan növekvő globális népességhez vezettek. A Nyugat-Európából kiinduló, a 1819. században bekövetkező technológiai, közegészségügyi és társadalmi változások hatására a második fázisban a halandóság a világban lassan javulni kezdett, azonban a termékenység változatlanul magas maradt, így gyors népességnövekedés vette kezdetét sorról sorra a világ nagyobb térségeiben. A 3. és 4. fázisban a halálozási arányszám csökkenése mellett a születési arányszám még jelentősebben kezd el csökkeni, így a népesség növekedése lassan stabilizálódik, majd az 5. fázisra mind a halálozási, mind a születési arányszám alacsony szinten stabilizálódik, így a népesség növekedése megáll (Andorka, 2006).

Tanulmányomban a fertilitási ráták segítségével vizsgálom meg, hogy a világ országai a demográfiai átmeneten miként haladnak át, a teljes termékenységi arányszámmal a születési arányszámot, a reprodukciós szinthez tartozó fertilitási rátával pedig halálozási arányszámot becsülve. Az első mutató jó mutatója a termékenységnek, hisz megadja, hogy a szülőképes korú nők életük során mennyi gyermeknek adnának életet, ha ha az adott év termékenységi adatai állandósulnának (Demográfia, 2020), a reprodukciós szinthez tartozó fertilitási ráta számítása során pedig a szülőképes korig használjuk fel a mortalitási mutatókat, így a mutató az adott ország halálozási mutatóinak is jó leképezője. Hosszú távon, ceteris paribus egy ország népessége növekszik, ha a teljes termékenységi arányszám nagyobb, mint a reprodukciós szinthez tartozó fertilitási ráta, és csökken, ha a termékenység a reprodukciós szint alá kerül. Tanulmányomban a két mutató értékeinek változását elemzem 1950-ben, 2015-ben, illetve 2040-ben. Egyéb demográfiai változókkal karöltve végzek klaszterelemzést 1950-ből, illetve napjainkból származó adatokkal, hogy megállapítsam az egyes térségek főbb tendenciát.

A tanulmány következő 2. fejezetében röviden áttekintem a témához kapcsolódó fontosabb szakirodalmakat, a 3. fejezetben bemutatom a fontosabb változókat és klaszterelemzés módszertanát, a 4. fejezetben pedig bemutatom az eredményeket, majd a záró fejezetben öszszegzem a tanulmány megállapításait.

\section{SZAKIRODALMI ÁTTEKINTÉS}

Egy ország népességének nagymértékű átstruktúrálódása jellemzően mindig valamilyen technológiai paradigmaváltáshoz kötődik. Globális tekintetben a kőeszközök elterjedése, majd a vadászó-gyűjtögető életmódról a mezőgazdaságra és állattenyésztésre való áttérés növelte meg először jelentősen az egyének túlélési esélyeit, mely lassú, globális népességnövekedéshez vezetett. A legkiterjedtebb és legnagyobb horderejű változás azonban a 1819. században, legelőször Nyugat-Európában végbemenő gyors technológiai és tudományos fejlődés következménye. A javuló mortalitási mutatók miatt a térség népességnövekedése jelentősen meglódult (lásd 1. táblázat), amely később a világ minden egyes részén teret nyert. Mára Európában a ciklus azonban szinte teljesen lezárult, alacsony születési és halálozási arányszámok jellemzőek a térségben, az országok nagy részében a népesség már érdemben nem növekszik.

Globális tekintetben is egyre inkább ez érvényesül, ugyanis az ENSZ (2019) előrejelzései alapján az évszázadunk elején becsült 1,29\%-os népességnövekedési ráta 2100-ig évi 0,03\%-osra lassulhat. A világ országai között természetesen továbbra is nagy különbségek adódnak, hisz egyes térségekben a nők továbbra is akár 5-nél is több gyermeket vállalnak (pl.: Niger, Mali, Csád), máshol viszont az átlagos 
1. táblázat: Becsült és várható népesség, illetve az éves népességnövekedési ütem európai országokban 1750-2100 között (millió föben)

\begin{tabular}{c|c|c|c|c|c|c|c|c}
\hline \multirow{2}{*}{} & \multicolumn{2}{|c|}{ Franciaország } & \multicolumn{2}{c|}{ Németország } & \multicolumn{2}{c|}{ Hollandia } & \multicolumn{2}{c}{ Magyarország } \\
\cline { 2 - 9 } & $\begin{array}{c}\text { Népes- } \\
\text { ség } \\
\text { (m. fö) }\end{array}$ & $\begin{array}{c}\text { Növe- } \\
\text { kedési } \\
\text { ütem }\end{array}$ & $\begin{array}{c}\text { Népes- } \\
\text { ség } \\
(\mathbf{m} . \mathbf{f o ̈})\end{array}$ & $\begin{array}{c}\text { Növe- } \\
\text { kedési } \\
\text { ütem }\end{array}$ & $\begin{array}{c}\text { Népes- } \\
\text { ség } \\
\text { (m. fö) }\end{array}$ & $\begin{array}{c}\text { Növe- } \\
\text { kedési } \\
\text { ütem }\end{array}$ & $\begin{array}{c}\text { Népes- } \\
\text { ség } \\
(\mathbf{m} . \text { fó) }\end{array}$ & $\begin{array}{c}\text { Növe- } \\
\text { kedési } \\
\text { ütem }\end{array}$ \\
\hline 1750 & 25000 & - & 15000 & - & 1900 & - & - & - \\
\hline 1800 & 27349 & $0,179 \%$ & 22377 & $0,803 \%$ & 2047 & $0,149 \%$ & - & - \\
\hline 1850 & 37366 & $0,626 \%$ & 33413 & $0,805 \%$ & 3057 & $0,805 \%$ & - & - \\
\hline 1900 & 38451 & $0,057 \%$ & 56637 & $1,061 \%$ & 5104 & $1,03 \%$ & 6854 & - \\
\hline 1950 & 41736 & $0,164 \%$ & 68376 & $0,377 \%$ & 10114 & $1,377 \%$ & 9293 & $0,611 \%$ \\
\hline 2000 & 59015 & $0,695 \%$ & 81401 & $0,349 \%$ & 15926 & $0,912 \%$ & 10043 & $0,155 \%$ \\
\hline 2050 & 67587 & $0,272 \%$ & 80140 & $-0,056 \%$ & 17165 & $0,15 \%$ & 9042 & $-0,21 \%$ \\
\hline 2100 & 65498 & $-0,063 \%$ & 74741 & $-0,218 \%$ & 15760 & $-0,171 \%$ & 7887 & $-0,273 \%$ \\
\hline
\end{tabular}

Forrás: Saját szerkesztés Haines (2001), KSH (2020), illetve az ENSZ (2019) adatai alapján

gyermekszám az 1-et is alig haladja meg (pl.: Dél-Korea, Tajvan). Az eltérés erősen magyarázható az egyes térségek fejlettségével is: a fejlettség és a termékenység között fordított J-alakú kapcsolat figyelhető meg, vagyis globálisan egy ország fejlettségének növekedése érdemben csökkenti a teljes termékenységi arányszám értékét, ám egy viszonylag magas fejlettségi szinttől már enyhén emeli (Myrskylä et al., 2009). A gazdasági fejlettség mellett a csökkenő termékenység okai között még az együttélés formájának megváltozása (házasságok számának csökkenése/élettársi kapcsolat előretörése, válások számának növekedése) (Buck és Scott, 1994), a nők fokozódó gazdasági függetlenedése (Cherlin, 1992), munkaerőpiaci aktivitásának erősödése (Rosenfeld és Birkelund, 1995) és az egyedül élő személyek elfogadottságának növekedése (Furstenberg, 1992) is megemlíthető.

Emellett a gyermek-kép is átalakult az évszázadok során: a gyermekhalálozások visszaszorulásával egy gyermek értéke „megnövekedett", erősödött az irányukba mutatott érzelmi kötődés és az érdek is, hogy megfelelő képzést kapjanak (Stone 1977, Schlumbohm, 1980). A társadalom átalakulásával, a növekvő egészség- ügyi és oktatási költségek miatt a gyermekek felnevelése egyre többe került, és a gyermekek első munkavállalási időpontjának kitolódásával ma már a szülőknek jellemzően tovább és több pénzzel kell támogatni gyermekeiket, mely az alacsony vagy nulla fertilitást egyre racionálisabbá teheti. A jólét növekedésével a világ összes országában egyre növekszik - tisztán közgazdaságtan megközelítés alapján - a gyermekvállaláshoz kapcsolódó költségek nagysága, így a gyermekvállalási hajlandóság visszaszorulása a jövőben is megmaradhat.

\section{VÁLTOZÓK ÉS A MÓDSZERTAN BEMUTATÁSA}

A klaszterelemzés egy osztályozó eljárás, amelynek célja megmutatni a megfigyelt sokaságon belül, hogy létezik-e az elemeknek olyan csoportja, részsokasága, amelyben az elemek a vizsgált ismérvek mentén jobban hasonlítanak egymáshoz, mint a sokaság többi eleméhez. A klaszterelemzés több módon végezhető el, attól függően, hogy pontosan milyen algoritmus alapján történik az elemek klasszifikálása, valamint, hogy milyen távolságmetrikát, illetve az adatoknak milyen standardizált formáját hasz- 


\begin{tabular}{c|c|c|c|c|c}
\hline & TTA & RSZTFR & $\begin{array}{c}\text { Medián } \\
\text { életkor }\end{array}$ & $\begin{array}{c}\text { Gyer- } \\
\text { mekkori } \\
\text { függóségi } \\
\text { ráta }\end{array}$ & $\begin{array}{c}\text { Időskori } \\
\text { függóségi } \\
\text { ráta }\end{array}$ \\
\hline TTA & 1 & & & & \\
\hline RSZTFR & 0,84 & 1 & & & \\
\hline Medián életkor & $-0,89$ & $-0,74$ & 1 & & \\
\hline Gyermekkori függőségi ráta & 0,98 & 0,82 & $-0,93$ & 1 & \\
\hline Időskori függőségi ráta & $-0,68$ & $-0,57$ & 0,90 & $-0,71$ & 1 \\
\hline
\end{tabular}

Forrás: Saját számítás az ENSZ (2019) adatai alapján

náljuk (Kovács, 2014). A kutatás során én sztenderdizált adatokon hierarchikus klaszterelemzést használtam Ward módszerrel, amelyben a program a pontok euklideszi távolságainak négyzetei alapján optimalizált. A klaszterelemzés előírása, hogy a maximális klaszterszám nem haladhatja meg a megfigyelések gyökét $(\sqrt{195} \approx 13,96)$, vagyis jelen tanulmányban maximum 13-14 klaszter képezhető (Kovács, 2014). Továbbá a kívánt klaszterszám kiválasztásakor a

$$
k \leq \sqrt{\frac{n}{2}}
$$

hüvelykujj szabály is alkalmazható, így végül 10 klaszterrel végeztem el az elemzésemet $(\sqrt{195 / 2} \approx 9,87)$ (Kovács, 2014).

A klaszterelemzést 195 országra végzem el, mely országokban él ma a világ össznépességének 99,95\%-a. Egyes országok 1950-ben még nem léteztek, azonban ezen országokra is voltak visszamenőleg adatok, így az elemzés egész időtávján 195 országgal tudtam elemezni. Az elemzésben 5 változót szerepeltettem: teljes termékenységi arányszám, reprodukciós szinthez tartozó fertilitás, gyermekkori függőségi ráta, időskori függőségi ráta és medián életkor. Az utóbbi három változó szerepeltetésének célja, hogy a fertilitási mutatók mellett az országok jelenlegi demográfiai képe is megjelenjen az eredményekben: a gyermekkori függőségi ráta (0-14 évesek/15-64 évesek) a fiatal generáció arányáról, az időskori függőségi ráta (65+ éve- sek/15-64 évesek) és a medián életkor pedig az idősebb generációkról árul el sokat egy adott országban. Az öt változó egymás közötti korrelációja eléggé erős (2. táblázat), amely miatt a klaszterelemzés szeparáló tulajdonsága sajnos kevésbé érvényesülhet. A korreláció erőssége és iránya nagyjából az intuíciónak és az elméletnek megfelelő, hisz például a demográfiai átmenet elején lévő országban magas a teljes termékenységi arányszám értéke, így a gyermekkori függőségi ráta is, továbbá a várhatóan alacsony fejlettségi szint miatt a mortalitási mutatók is rosszak, így a reprodukciós szinthez tartozó fertilitási értéke magas, a medián életkor és az időskori függőségi ráta értéke pedig alacsony.

A reprodukciós szinthez tartozó fertilitási ráta nem volt közvetlenül elérhető az ENSZ adatbázisban, kiszámításához a Világbank (2019) és az ENSZ (2019) adatbázisait használtam fel, amelyek éves vagy ötéves intervallumban tartalmazzák a kohorszok szerinti népesség- és halálozási számadatokat, a nemek születéskori arányát, az egyes kohorszok halálozási számait és a várható élettartamot 1950től 2100-ig. Három ország adatsora nem volt teljes, ezen országok reprodukciós szinthez tartozó fertilitási rátáját a hiányzó évekre más országok értékei alapján becsültem. ${ }^{1}$ A mutató becslése során az adott évi halálozási és kohorszszám alapján számítódott a korosztályi túlélési ráta $(p)$, mely a reprodukciós szinthez tartozó fertilitási ráta számításának alapja²: 


\section{Tudományos mühely}

3. táblázat: A teljes termékenységi arányszám és a reprodukciós szinthez tartozó fertilitási ráta 1950-ben

\begin{tabular}{c|c|c}
\hline & TTA & RSZTFR \\
\hline Átlag* & 5,05 & 2,99 \\
\hline Medián & 6,00 & 2,82 \\
\hline Minimum & 1,98 & 2,12 \\
\hline Maximum & 8,00 & 4,87 \\
\hline Alsó kvartilis & 4,15 & 2,43 \\
\hline Felsó kvartilis & 6,70 & 3,42 \\
\hline Szórás & 1,65 & 0,64 \\
\hline Relatív szórás & $32,77 \%$ & $21,27 \%$ \\
\hline
\end{tabular}

*Népességszámmal súlyozva. Forrás: Saját számitás az ENSZ (2019) alapján 1950 és 1950-1950-es adatokkal

$$
\operatorname{RSZTFR}_{T}=\frac{1 / \sum_{t=1}^{6} p_{5 t}}{S R_{T}}
$$

A 30 éves korig fennálló ötévenkénti túlélési adatok $(p)$ szorzatának reciproka és a megszülető gyermekekre jutó lányok $(S R)$ hányadának aránya adja meg a reprodukciós szinthez tartozó fertilitási ráta értékét. Vagyis a ráta számításakor fennálló megoszlása a születéseknek nemek szerint illetve a nők körében az elkövetkező 30 évben várható mortalitási adatok határozzák meg egy adott országban a reprodukciós szinthez tartozó fertilitási ráta értékét. Adathiány miatt 30 évet határoztam meg anyai életkornak, azonban 15 és 40 éves kor között nagyon kevés nő hal meg, így ez valószínűleg érdemben nem befolyásolta az eredményeket.

\section{EREDMÉNYEK}

Az elkövetkezőkben először idősorosan, három időpontban $(1950,2015,2040)$ vizsgálom meg a teljes termékenységi arányszám, illetve a reprodukciós szinthez tartozó fertilitási ráta alakulását, majd az 1950 és a 2015-2020-as adatokon alapulva keresztmetszeti módon, öt változóval végzett két klaszterelemzés főbb eredményeit mutatom be.

1950-ben még a világ népességének 97\%-a olyan országban lakott, ahol a a teljes termé- kenységi arányszám értéke meghaladta a reprodukciós szinthez tartozó fertilitási ráta értékét. A teljes termékenységi arányszám átlagosan több, mint 2-vel volt nagyobb, mint a reprodukciós szinthez tartozó fertilitási ráta. Viszonylag sok országban viszont még nagyobb volt az eltérés, erre példa, hogy a medián, illetve a felső kvartilis esetében a két mutató értékében az eltérés inkább 3 közeli. A két mutató értékei viszonylag nagy terjedelmet fedtek le akkoriban, a teljes termékenységi arányszám, illetve a reprodukciós szinthez tartozó fertilitási ráta relatív szórása 32,77\%, illetve 21,27\% környékén alakult.

Ezzel szemben napjainkra a reprodukciós szinthez tartozó fertilitási ráta értékeinek terjedelme jelentősen szűkült, a relatív szórás már csak 5,48\% körül alakul. A teljes termékenységi arányszám értékei még jelentősebben csökkentek az elmúlt évtizedekben, ám ez szemben a reprodukciós szinthez tartozó fertilitási rátával ahol leginkább a fejletlen térségek mutatói csökkentek, ez szinte az egész sokaságot érintette, így a relatív szórás még emelkedett is az említett időtávon. A változások hatására a két mutató közötti eltérés jelentősen szűkült, így ma már csak a világ népességének kevesebb mint egyharmada él olyan országban, ahol nagyobb a teljes termékenységi arányszám, mint a reprodukciós szinthez tartozó fer- 


\section{Tudományos mühely}

4. táblázat: A teljes termékenységi arányszám és a reprodukciós szinthez tartozó fertilitási ráta 2015-ben

\begin{tabular}{c|c|c}
\hline & TTA & RSZTFR \\
\hline Átlag* & 2,42 & 2,19 \\
\hline Medián & 2,24 & 2,11 \\
\hline Minimum & 1,11 & 2,06 \\
\hline Maximum & 6,95 & 2,64 \\
\hline Alsó kvartilis & 1,72 & 2,08 \\
\hline Felsó kvartilis & 3,59 & 2,20 \\
\hline Szórás & 1,27 & 0,12 \\
\hline Relatív szórás & $52,56 \%$ & $5,48 \%$ \\
\hline
\end{tabular}

*Népességszámmal súlyozva. Forrás: Saját számitás az ENSZ (2019) alapján 2015 és 2015-2020-as adatokkal

tilitási ráta. Ez azt is jelenti, hogy ha világon nem javulnának a mortalitási mutatók, akkor középtávon a világ népességének kétharmada már olyan országban élne, ahol a lakosság lélekszáma csökkenő.

A jövőben az ENSZ előrejelzési szerint a folyamatok hasonlóan alakulhatnak: a világ népességének már csak 28\%-a fog olyan országban élni, ahol a két mutató értéke pozitív, így hosszú távon - ceteris paribus - növekedő a népesség. A teljes termékenységi arányszám értéke már a reprodukciós szinthez tartozó fertilitási ráta értékét közelítheti, és mindkét mutató értéke és relatív szórása tovább csökkenne. Ez a világ népességének növekedését is jelentősen lelassíthatja, évszázadunk második felében várhatóan már csak 1 milliárd fővel bővül a világ népessége, míg 2000-2050 között a bővülés több, mint 2,5 milliárd fö.

$\mathrm{Az}$ öt változóval elvégzett klaszterelemzés eredményeit 1950-re és 2015-2020-ra vonatkozóan az 1. és 2. ábra tartalmazza. ${ }^{3} \mathrm{Az} 1$. ábrán a klaszterek a klasztercsoport átlagos teljes termékenységi arányszáma alapján kerültek sorbaállításra, így látható, hogy az átlagosan legkisebb értékkel rendelkező országok jellemzően euró-

5. táblázat: A teljes termékenységi arányszám és a reprodukciós szinthez tartozó fertilitási ráta 2040-ben

\begin{tabular}{c|c|c}
\hline & TTA & RSZTFR \\
\hline Átlag* & 2,16 & 2,14 \\
\hline Medián & 1,88 & 2,09 \\
\hline Minimum & 1,32 & 2,05 \\
\hline Maximum & 4,70 & 2,37 \\
\hline Alsó kvartilis & 1,68 & 2,07 \\
\hline Felső kvartilis & 2,56 & 2,12 \\
\hline Szórás & 0,70 & 0,06 \\
\hline Relatív szórás & $32,60 \%$ & $2,72 \%$ \\
\hline
\end{tabular}

*Népességszámmal súlyozva. Forrás: Saját számitás az ENSZ (2019) alapján 2040 és 2040-2045-ös adatokkal 
1. ábra: A klaszterek elhelyezkedése a Ward módszerrel elvégzett hierarchikus klaszterelemzés után 1950-es adatokon, a klaszterek számozása a teljes termékenységi arányszám klaszterátlagai alapján (1 - TTA legkisebb; 10 - TTA legnagyobb)

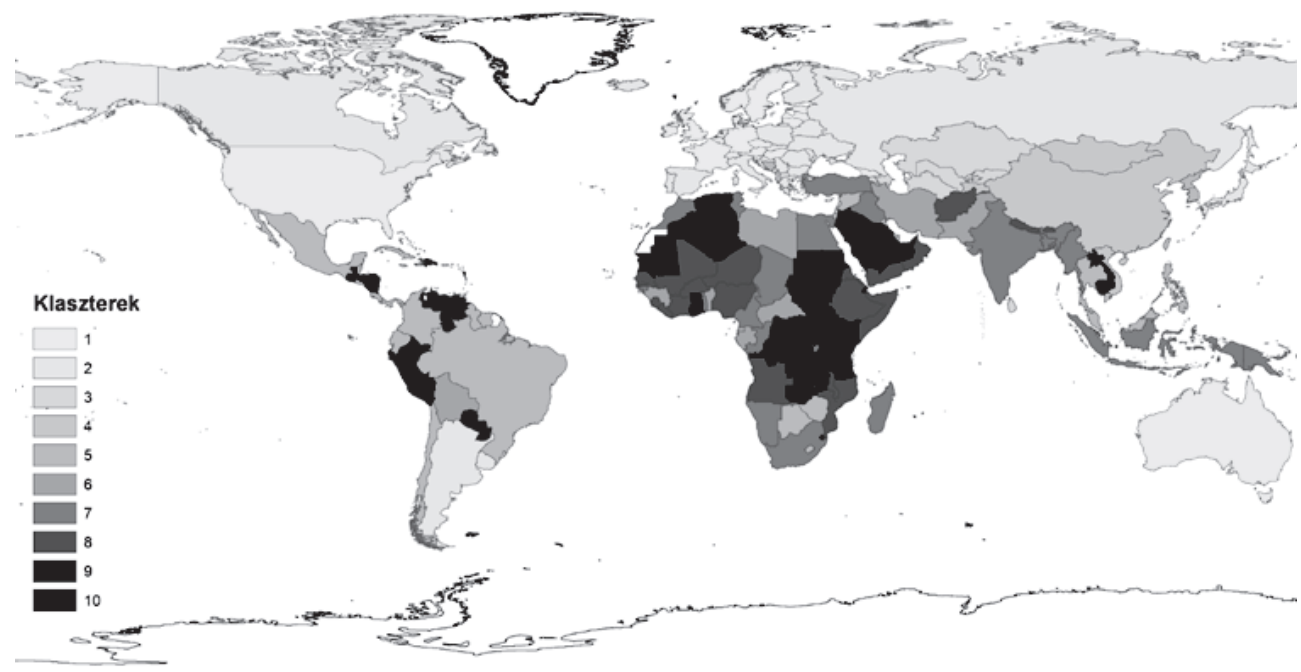

Forrás: Saját szerkesztés ENSZ (2019) adatai alapján ArcMap program segítségével

pai országok, míg a legnagyobb értékkel rendelkezők kivétel nélkül Afrika legszegényegebb országai. A klasztercsoportok között érdemi átrendeződés történt 1950 és 2015-2020 között. A II. világháború után ugyanis a harmadik világ országai között nagyrészt egyenlően oszlottak még meg a demográfiai átmenet legelején álló országok. Az 1950-es évek adatai alapján készült klaszterelemzés kapcsán a legmagasabb teljes termékenységi arányszámmal rendelkező klaszterben 12 afrikai, 5 ázsiai, 5 latin-amerikai és 2 óceániai ország szerepelt. Ellenben a 2015-ös adatokon elvégzett klaszterelemzés során az utolsó klaszterben már csak afrikai országok voltak jelen (Közép-afrikai Köztársaság, Csád, Kongói Demokratikus Köztársaság, Mali, Niger, Nigéria, Sierra Leona, Szomália), és itt még mindig az 1950-es éveket idéző volt a teljes termékenységi arányszám és a reprodukciós szinthez tartozó fertilitási ráta közötti eltérés mértéke.

Emiatt az elkövetkező években ezen országokban folytatódhat a népességrobbanás, a 8 ország 2015-ben 336 milliós népessége 2040-ig várhatóan évi 2,63\%-os népességnövekedéssel
642 millióig növekedhet. A túlnépesedés vagy a túlságosan gyors népességnövekedés szakszó használata így ezen országokra nézve továbbra is teljesen megalapozottnak tűnik.

Azonban Afrika és pár ázsiai (pl.: Afganisztán Jemen, Irak és Pápua Új-Guinea) országot leszámítva a legtöbb fejlődő országra már nem jellemző a teljes termékenységi arányszám és a reprodukciós szinthez tartozó fertilitási ráta érdemi eltérése. A legnépesebb fejlődő országok közül Kínában, Brazíliában már kevesebb gyermeket vállalnak, mint ami ceteris paribus kellene a népesség fenntartásához, Indiában, Mexikóban és Bangladesben a két mutató értéke nagyjából megegyezik és Pakisztánban is csak átlagosan nagyjából 1-el vállalnak több gyermeket, mint ami a reprodukcióhoz szükséges lenne.

A világ 10 legnépesebb országa közül egyedül Nigéria esete kiugró, ahol még most is közel 3 a két mutató különbsége. A fejlődő országok gyors átakulására példa a 4-es klasztercsoport (Maldív-szigetek, Bahrein, Brunei, Kuvait, Omán, Katar, Szaúd-Arábia, Egyesült Arab Emírségek) is, mely jellemzően a mára kőolaj- 
2. ábra: A klaszterek elhelyezkedése a Ward módszerrel elvégzett hierarchikus klaszterelemzés után 2015-ös adatokon, a klaszterek számozása a teljes termékenységi arányszám klaszterátlagai alapján (1 - TTA legkisebb; 10 - TTA legnagyobb))

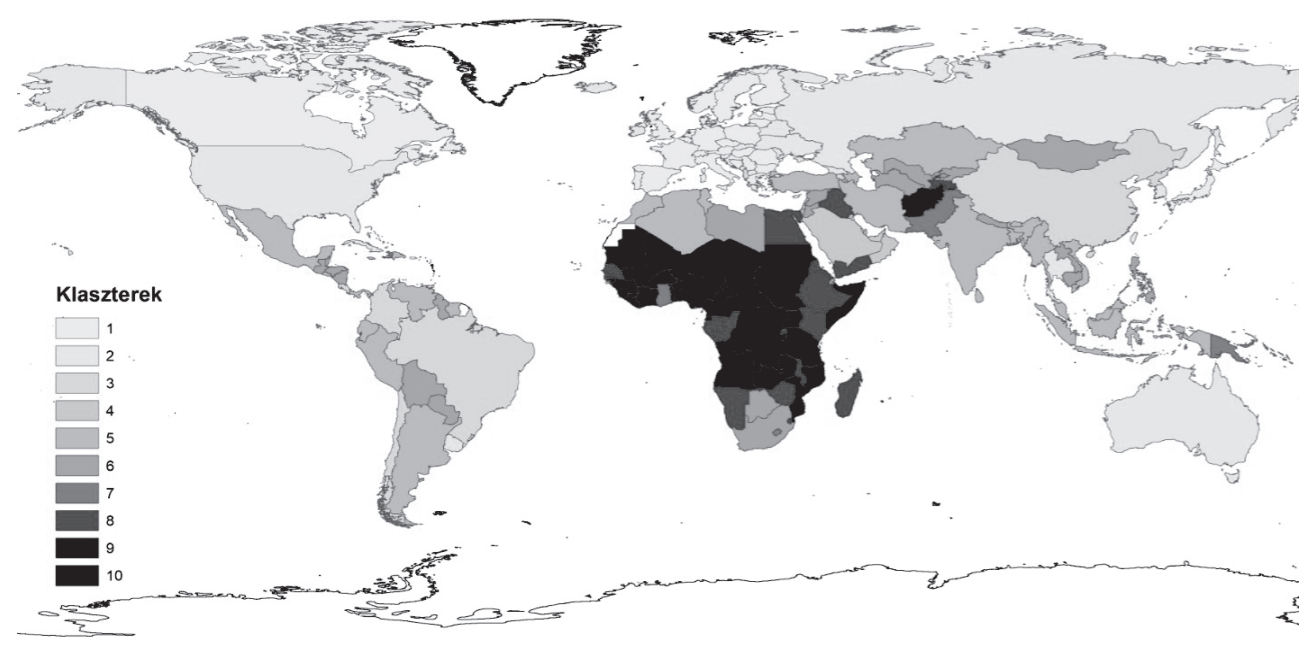

Forrás: Saját szerkesztés ENSZ (2019) adatai alapján ArcMap program segítségével

termelésből meggazdagodó államokat tartalmaz. Ezen országok gyors meggazdagodása a társadalmi és demográfiai átmenetet rendkívüli mértékben felgyorsította: a teljes termékenységi arányszám ezekben az országokban ma már a reprodukciós szint alatt alakul, azonban a mutató korábbi nagyon magas értékeit sejteti, hogy az időskori függőségi ráta az összes klaszter közül itt a legalacsonyabb. Szaúd-Arábiában például az olajárrobbanást megelőzően még átlagosan 7,3 gyermeket vállaltak a szülők, mára azonban ez az érték 2,34-re csökkent. Az ország Bahrainnel és az Egyesült Arab Emírségekkel karöltve 1950-ben még a legnagyobb teljes termékenységi arányszámmal rendelkező klasztercsoportba tartozott, mára azonban már csak a 6. legnagyobba.

A demográfiai átmenetben való gyors előrehaladás alapvetően Afrikán kívüli fejlődő térségben volt jellemző. Ezt jól mutatja, hogy 1950-ben még a 8., 9. és 10. klasztercsoportban lévő országok 50\%-a volt afrikai, addig 2015-re ez az arány 79\%-ra nőtt. Afrika lemaradását érzékelteti a 6. táblázat is. Az afrikai országokhoz kapcsolódó klaszterszámok átlaga egyedül ezen a kontinensen növekedett a vizsgált időtávban. Ez két okból is figyelemreméltó: egyrészt az alacsony teljes termékenységi arányszámmal rendelkező klaszterekbe 2015-be relatíve több ország került, mint 1950-ben, így a klaszterszámok átlaga alapvetően is 0,57-el csökkent. Másrészt már az 1950-es években is relatíve nagy volt a lemaradása az afrikai országoknak (átlag: 7,63), mely relatív lemaradás napjainkig még tovább növekedett. Ez nem azt jelenti, hogy az afrikai országokban ne kezdődött volna el a demográfiai átmenet, a születések számának csökkenése, azonban ez a folyamat a kontinensen összességében csigalassúságú más fejlődő térséghez viszonyítva.

A gazdasági fejlődés mértéke és a demográfiai átmenet gyorsasága ezen elemzés kapcsán is részben előtűnik. 1950 és 2015 között összesen 8 ország lépett „előre” legalább 5 klasztert. Ezen országokban az elmúlt években jelentős gazdasági növekedés ment végbe: Algéria és Peru kivételével ezen országokban vagy az olaj (Bahrain, Egyesült Arab Emírségek, Szaúd-Arábia) vagy a turizmus (Dominikai Köztársaság, Mauritius, Saint Vincent és a Grena- 
Tudományos mühely

6. táblázat: Az egyes kontinensen lévő országok klaszterszámátlagainak* változása 1950 és 2015-2020 között

\begin{tabular}{c|c|c|c}
\hline & $\mathbf{1 9 5 0}$ & $\mathbf{2 0 1 5 - 2 0 2 0}$ & Különbség \\
\hline Afrika & 7,63 & 8,11 & 0,48 \\
\hline Amerika & 5,7 & 3,92 & $-1,78$ \\
\hline Ázsia & 5,78 & 4,86 & $-0,92$ \\
\hline Óceánia & 6,08 & 5,58 & $-0,5$ \\
\hline Európa & 1,78 & 1,32 & $-0,46$ \\
\hline Világ & 5,46 & 4,88 & $-0,57$ \\
\hline
\end{tabular}

*Országgal súlyozva. Forrás: Saját számítás az ENSZ (2019) alapján 1950 és 2015-2020-as adatokkal

dine-szigetek) járult hozzá jelentős mértékben a gazdasági fejlődéséhez. Ellenben 13 ország lépett „vissza” legalább 3 klasztert, köztük a csődök során keresztülmenő Argentína, polgárháborúkban megtépázott afrikai országok (pl.: Zimbabwe, Csád, Közép-afrikai Köztársaság), illetve a Szovjetunió felbomlása után jelentős és hosszan tartó gazdasági pangást megélt délszovjet utódállamok (Kirgizisztán, Türkmenisztán, Üzbegisztán, Tádzsikisztán).

\section{ÖssZegzés}

A tanulmányban a fertilitási rátákon keresztül tekintettem át a fóbb demográfiai folyamatokat. A gazdasági és társadalmi folyamatok hatására az elmúlt években a fertilitási ráták jelentősen csökkentek számos fejlődő országban. Az 1950-től napjainkig a teljes termékenységi arányszám megfeleződése, illetve a reprodukciós szinthez tartozó fertilitási ráta jelentős csökkenése azonban egyenlőtlenül ment végbe. Egyrészt a fertilitási ráta relatív szórása érdemben nem csökkent globális mértékben, a reprodukciós szinthez tartozó fertilitási ráta relatív szórása azonban jelentősen mérséklődött, vagyis a mortalitási mutatók tekintetében 1950-hez képest az egyes országok egymástól való relatív távolsága jelentősen csökkent. A jövőben a két mutató értéke még tovább csökkenhet, azonban a teljes termékenységi arányszám nagyobb fokú csökkenésével párhuzamosan a magas születésszám egyre kevésbé határozhatja meg a világ népességének növekedését.

Másrészt az elmúlt évtizedek folyamatai eltérően érintették a világ különböző térségeit. Öszszességében az elmúlt évtizedekben sikeresebb, nagyobb gazdasági fejlődésen keresztülmenő országok a demográfiai átmeneten is gyorsabban haladnak keresztül. A fejlődő régiók közül az afrikai országok relatív lemaradása erősödött, a térségben a fertilitási mutatók továbbra is magas értékeket vesznek. Ezzel szemben Ázsia és Amerika kontinensén összességében gyors demográfiai átmenet ment végbe az elmúlt hetven évben, a térség országainak nagy részében a népességnövekedés jelentősen lelassult, a teljes termékenységi arányszám sok esetben már a reprodukciós szint alatt marad. Ez hosszú távon a népességnövekedés stagnálásba, csökkenésbe való fordulását és a térség elöregedését eredményezheti.

A kutatást az EFOP-3.6.2-16-2017-00017 azonositószámú „Fenntartható, intelligens és befogadó regionális és városi modellek" címü projekt, illetve az Innovációs és Technológiai Minisztérium, valamint a Nemzeti Kutatási, Fejlesztési és Innovációs Hivatal Kooperatív Doktori Programja támogatta.

\section{JEGYZETEK}

1 Montenegró, Szíria, valamint Makaó értékeivel helyettesítettem Szerbia, Palesztina és Tajvan hiányzó értékeit. 


\section{Tudományos mühely}

2 A ráta megadja, hogy mennyi gyermeket kell átlagosan egy nőnek szülnie ahhoz, hogy a szülőképes korú nők száma ceteris paribus ne csökkenjen.

3 Az elemzés a tanulmány fókusza miatt kizárólag a fertilitási eredmények bemutatására vonatkozik. Összességében a változók közötti magas korrelációs érték miatt a létrejött klaszterátlagok a korrelációs mátrix értékeihez igencsak hasonlóak, tehát a nagyobb átlagos teljes termékenységi arányszámmal rendelkező klaszterekben jellemzően magasabb a reproduciós szinthez tartozó fertilitási ráta és a gyermekkori függőségi ráta, míg alacsonyabb a medián életkor és az időskori függőségi ráta.

\section{FELHASZNÁLT SZAKIRODALOM}

Andorka Rudolf (2006): Bevezetés a Szociológiába. Osiris Kiadó.

Buck, N. - Scott, J. (1994): Household and family change. In N. Buck et. al.: Changing Households: The British Household Panel Survey 1990-1992. University of Essex: ESRC Centre on Micro-Social Change, 6182.

Cherlin, A. (1992): Marriage, Divorce, Remarriage. Cambridge: Harvard University Press.

Demográfia (2020): https://demografia.hu/hu/tudastar/fogalomtar/38-teljes-termekenysegi-aranyszam Letöltés ideje: 2020. március 30.

ENSZ (2018): http://www.un.org/en/development/ desa/population/ Letöltve: 2018. február 25.

ENSZ (2019): https://population.un.org/wpp/ Letöltés ideje: 2019. december 17.

Furstenberg, F. F, Jr. (1992): Family change and the welfare of children: What do we know and what can we do about? paper presented at the Seminar on Gender and Family Change in Industrialized Countries. Rome, January.

Haines, M. R. (2001): The population of Europe: The Demographic Transition and After. Encylopedia of European Social History. https://www.encyclopedia.com/international/encyclopedias-almanacs-transcripts-and-maps/population-europe-demographic-transition-and-after Letöltve: 2018. február 25.

Kovács Erzsébet (2014): Többváltozós adatelemzés. Typotex Kiadó

KSH (2018): http://www.ksh.hu/ Letöltve: 2020. július 9.

Myrskylä, M. - Kohler, H-P. - Billari, F.C. (2009): Advances in development reverse fertility declines. Nature 460.7256
(2009), pp. 741-743.

Rosenfeld, R. A. - Birkelund, G. E. (1995): Women's parttime work: A cross-national comparison. European Sociological Review 11. pp. 111-134.

Schlumbohm, J. (1980): Traditional collectivity and modern individuality: Some questions and suggestions for the historical study of socialization: The examples of the German lower and upper bourgeoisie around 1800. Social History 5: pp. 71-103.

Stone, L. (1977): The Family, Sex and Marriage in England 1500-1800. New York: Harper and Row.

Világbank (2019): https://data.worldbank.org/ Letöltés ideje: 2019. december 10. 